\title{
Anthropogenic disturbances alter the conservation value of karst dolines
}

\author{
${\text { Zoltán Bátori }{ }^{1} \text { (D) . András Vojtkó }}^{2}$ Gunnar Keppel ${ }^{3,4}$. Csaba Tölgyesi ${ }^{1}$. \\ Andraž Čarni ${ }^{5,6}$ - Matija Zorn ${ }^{7}$. Tünde Farkas ${ }^{8}$. László Erdős ${ }^{9} \cdot$ Péter János Kiss ${ }^{1,10}$. \\ Gábor Módra $^{1,10} \cdot$ Mateja Breg Valjavec ${ }^{7}$
}

Received: 1 July 2019 / Revised: 27 September 2019 / Accepted: 26 October 2019 /

Published online: 9 November 2019

(C) The Author(s) 2019

\begin{abstract}
Dolines are depressions in karst landscapes that are of high value for conservation, providing habitats and supporting species not found in the surrounding landscape. This is due to their high microhabitat diversity and ability to decouple microclimate from regional climate changes, making them potential refugia for biodiversity. Nevertheless, local anthropogenic disturbances have had considerable impact on the species composition and vegetation structure of many dolines. Here we investigate the conservation value of dolines in three European karst areas, where different levels and types of anthropogenic disturbances have been shaping the vegetation for centuries, using the number of plant species that are cool-adapted, moist-adapted and of high conservation importance (i.e. vulnerable species) as indicators. We found that anthropogenic disturbances generally have a negative impact, reducing the number of vulnerable species supported by dolines. However, more cooladapted and moist-adapted species were found in some dolines planted with non-native Picea abies than in less disturbed dolines, indicating that anthropogenic disturbances can also have positive consequences for biodiversity. We conclude that anthropogenic disturbances alter the capacity of dolines to support vulnerable species, and that this will impact survival of species in landscapes under global warming. In this context, the effects of various disturbances on species composition and diversity need to carefully considered to determine the best conservation and/or management options.
\end{abstract}

Keywords Climate change $\cdot$ Karst depression $\cdot$ Logging $\cdot$ Microrefugia $\cdot$ Safe haven Vulnerable species $\cdot$ Vegetation

Communicated by David Hawksworth.

Electronic supplementary material The online version of this article (https://doi.org/10.1007/s1053 1-019-01896-4) contains supplementary material, which is available to authorized users.

Zoltán Bátori

zbatory@gmail.com

Extended author information available on the last page of the article 


\section{Introduction}

The complex topography of karst systems provides various habitats where species can survive during local and regional environmental changes (Antonić et al. 2001; Wezel 2007; Bátori et al. 2014a). Enclosed depressions in karst landscapes (dolines) have several characteristics that make them primary candidates for such safe havens, which may offer the best hope for in situ persistence of vulnerable species (Horvat 1953; Dobrowski 2010; Bátori et al. 2017). Dolines provide steep gradients of environmental conditions (e.g., soil moisture and temperature) within very short distances (Whiteman et al. 2004; Chauchard et al. 2007; Su et al. 2017), enabling them to facilitate the persistence of various functional groups of species in various phyla (Růžička et al. 2016; Breg Valjavec et al. 2018a; Bátori et al. 2019). As a result, they are characterised by high genetic (Egli 1991; Su et al. 2017), taxonomic (Bátori et al. 2014b; Kemencei et al. 2014; Raschmanová et al. 2015; Růžička et al. 2016; Battisti et al. 2017) and microhabitat diversity (Özkan et al. 2010; Bátori et al. 2019) and may offer the best chances of survival for cool-adapted species and/or species retreating from global warming (i.e. trailing edge and stabilized relict populations) (Hampe and Petit 2005; Bauer 2018; Bátori et al. 2019). Because of their significant impact on a region's biodiversity, they are particularly important for conservation planning.

Considerable progress has been made in identifying and understanding locations with high resistance to environmental changes (Ashcroft 2010; Bátori et al. 2017; Maclean et al. 2017; Meineri and Hylander 2017). It has also been recognized that such locations, also known as refugia, differ in their capacity to facilitate the persistence of biodiversity (Keppel et al. 2015; Keppel and Wardell-Johnson 2015). However, anthropogenic disturbances may greatly affect vegetation structure, species composition and habitat diversity (Mishra et al. 2004; Serra-Diaz et al. 2015), but have hardly been considered when discussing refugia. In general, changes in vegetation structure can affect the surface albedo, air temperature, wind pattern, soil moisture and nutrient content (Saikh et al. 1998; Guariguata and Ostertag 2001; Berbet and Costa 2003; Greiser et al. 2018; Stančič and Repe 2018), which in turn, are bound to affect the buffering and decoupling capacity of habitats (cf. Lenoir et al. 2017). Variations in these environmental factors in response to disturbance may cause local extinctions (Gibb et al. 2018) and provide specific niches in which fast-growing disturbance-tolerant species have an advantage over other species (Somodi et al. 2008). Responses to such disturbance will depend on how well resident species recover from disturbance and compete with newcomers (Serra-Diaz et al. 2015). Therefore, the effects of various disturbances need to be considered for reliable predictive species distribution modelling (Guisan and Wilfried 2005; Syphard and Franklin 2010) and when identifying potential refugia under climate change (Keppel et al. 2015; Morelli et al. 2016).

Dolines and their unique biota are particularly vulnerable to anthropogenic disturbances (De Waele 2009; Breg Valjavec et al. 2018b; Jian et al. 2018). For instance, road construction, overgrazing and nutrient addition by sheep have seriously threatened plants endemic to dolines in the Greek Archipelago biodiversity hotspot (Egli 1991; Brullo and Giusso del Galdo 2001; Iatroú and Fournaraki 2006). Furthermore, many dolines in Europe are used as dumping grounds or have been filled with construction waste (in order to create new lands for highways, industrial facilities and residential areas), while others have been transformed into agricultural fields or gardens (Parise and Pascali 2003; Kovačič and Ravbar 2013; Breg Valjavec 2014; Breg Valjavec et al. 
2018a). Such disturbances would have reduced or eliminated the capacity of these dolines to be safe havens for biodiversity. Therefore, assessing the capacity of refugia to support biodiversity under anthropogenic climate change requires an understanding of the effects of anthropogenic disturbances.

In this study we investigate the impact of anthropogenic disturbances on the conservation value of dolines in three European karst areas, where different levels and types of anthropogenic disturbances have been shaping the landscape for hundreds of years. We use the presence of plant species that are cool-adapted, moist-adapted (and hence indicate the retention of cooler and moister microhabitats) or considered to have high conservation importance inside and outside of dolines as indicators of conservation value. Specifically, the following questions were addressed: (i) Are there any differences between the number of cool-adapted, moist-adapted and high-conservation-importance plant species between dolines and surrounding plateaus? (ii) Do different levels and types of anthropogenic disturbances influence the distribution patterns of such species in dolines?

\section{Methods}

\section{Study sites}

Three karst regions were selected in Slovenia and Hungary, where the current vegetation in dolines has developed under varied disturbances. One study site was located in the

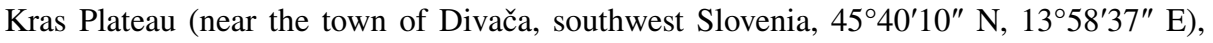
one in the Mecsek Mountains (near the villages of Abaliget and Orfü, southwest Hungary, $46^{\circ} 07^{\prime} 25^{\prime \prime} \mathrm{N}, 18^{\circ} 08^{\prime} 43^{\prime \prime} \mathrm{E}$ ), and two sites (forested and non-forested) in the Bükk Moun-

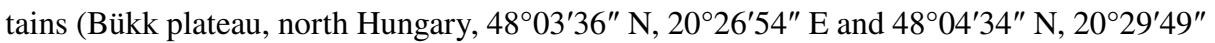
E) (Fig. 1a).

The study site in Kras (440 m asl; $\mathrm{T}_{\mathrm{a}}: 11.4{ }^{\circ} \mathrm{C}$; $\mathrm{P}_{\mathrm{a}}: 1250 \mathrm{~mm}$; www.en.climate-data.org) was almost totally treeless over centuries, and grasslands were heavily grazed by sheep (Kaligarič et al. 2006). Many dolines were transformed by removing stones from their bottoms and adding soil to increase suitability for agriculture (Kovačič and Ravbar 2013; Breg Valjavec et al. 2018a). These dolines (also known as 'cultural' dolines) have relatively steep slopes and flat bottoms, and are encircled by stone walls. However, the majority of these small agricultural lands have been abandoned in the last decades. Due to natural and artificial afforestation in Kras, forest cover increased significantly over the last 40-50 years (Zorn et al. 2015). Currently, semi-dry forests (with Acer monspessulanum, Fraxinus ornus, Ostrya carpinifolia and Quercus pubescens trees) and Pinus nigra plantations cover the plateaus between dolines, while mesic forests (with Acer campestre, Carpinus betulus and Tilia cordata trees) or non-native Picea abies plantations cover the bottoms of larger dolines (Fig. 1c, d).

Extensive commercial clear-cut logging has shaped the landscape of the study site in Mecsek (300-500 m asl; $\mathrm{T}_{\mathrm{a}}: 9.5^{\circ} \mathrm{C} ; \mathrm{P}_{\mathrm{a}}: 750 \mathrm{~mm}$, Dövényi 2010) for decades. Current forest stands mainly include $40-50,60-80$ or 90-120 year-old trees (Fig. 1e, f). Carpinus betulus, Fagus sylvatica, Quercus cerris and $Q$. petraea are the dominant tree species on the plateaus and upper slopes of dolines, while Acer campestre, A. platanoides, A. pseudoplatanus, Carpinus betulus, Fagus sylvatica and Fraxinus excelsior are dominant on the bottoms and lower slopes of larger dolines (Bátori et al. 2012, 2014b). 

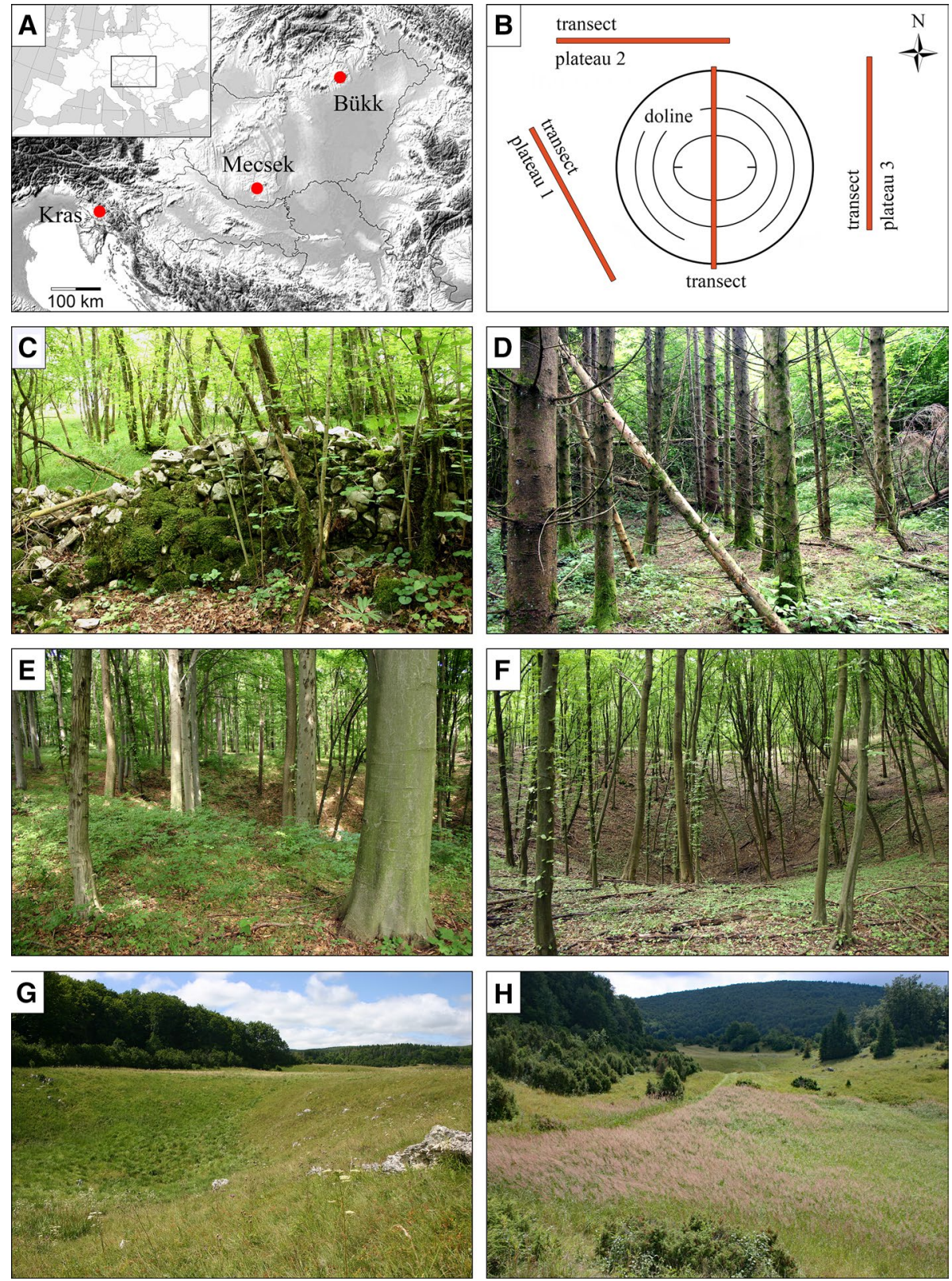

Fig. 1 Study regions, sampling design and study sites. a Location of the study regions in Slovenia and Hungary. b Sampling design. c Stone wall in a cultural doline in Kras (Slovenia). d Norway spruce plantation in a cultural doline in Kras. e Old beech forest ( $>90$ years) on the edge of a doline in Mecsek (Hungary). f Young ravine forest ( $<50$ years) in a doline in Mecsek. $\mathbf{g}$ Wet and semi-dry grasslands in a non-forested doline in Bükk (Hungary). h Invasion of Calamagrostis epigejos in a non-forested doline in Bükk 
The two study sites (forested and non-forested) in Bükk are located in the montane beech forest zone (700-900 m asl; $\mathrm{T}_{\mathrm{a}}: 6.3{ }^{\circ} \mathrm{C} ; \mathrm{P}_{\mathrm{a}}: 800 \mathrm{~mm}$, Dövényi 2010). Fagus sylvatica is the dominant tree species in the dolines and on the surrounding plateaus at the forested site. Non-native Picea abies plantations also occur in some larger dolines. Extensive forest areas were cut in the 19th century to convert forests to pastures and hay meadows, and to produce timber. The bottom of many dolines was used as lime kilns over decades. Currently, dolines and plateaus at the non-forested site maintain diverse grassland communities (Vojtkó 2001). Semi-dry and dry grasslands cover the south-facing slopes of dolines, while mesic and wet grasslands can be found on the bottoms and north-facing slopes (Fig. 1g). Previous cultivation has led to the invasion of a tall grass species, Calamagrostis epigejos, in many dolines (Fig. 1h).

\section{Sampling design}

Prior to sampling, we classified dolines and adjacent plateaus at each site into 'disturbance classes' (little, medium and high disturbance) based on the effects of previous and current human activities (Table 1). We considered all activity types that may have had a significant effect on current plant species composition, similarly to the method described by Van Beynen and Townsend (2005). We classified disturbance within sites at three levels; the vegetation of 'dolines with little disturbance' (class D1) has developed under the lowest disturbance levels; while the vegetation of 'dolines with high disturbance' (class D3) has

Table 1 Types of disturbances and disturbance classes (doline: D1: little, D2: medium and D3: high disturbance; plateau: D1R: little disturbance) in the dolines and on the plateaus in Slovenia (Kras) and Hungary (Mecsek, Bükk)

\begin{tabular}{|c|c|c|c|}
\hline Study sites & Types of disturbances & $\begin{array}{l}\text { Distur- } \\
\text { bance } \\
\text { classes }\end{array}$ & Number of plots \\
\hline \multirow[t]{3}{*}{ Kras (f) } & a.f. $<50$ years & D1 & 60 \\
\hline & a.f. $<50$ years; previous land filling & $\mathrm{D} 2$ & 56 \\
\hline & $\begin{array}{l}\text { a.f. }<50 \text { years; previous land filling; non-native plantation } \\
\quad(\text { Picea abies })\end{array}$ & D3 & 71 \\
\hline Kras (fp) & a.f. $<50$ years & D1R & 90 \\
\hline \multirow[t]{3}{*}{ Mecsek (f) } & a.f. $>90$ years & D1 & 100 \\
\hline & a.f. $60-70$ years; forest thinning (infrequent) & D2 & 94 \\
\hline & a.f. $<50$ years; forest thinning (regular) & D3 & 89 \\
\hline Mecsek (fp) & a.f. $>90$ years & D1R & 90 \\
\hline \multirow[t]{2}{*}{ Bükk (f) } & a.f. $>90$ years & D1 & 90 \\
\hline & a.f. $>90$ years; non-native plantation (Picea abies) & D2 & 89 \\
\hline Bükk (fp) & a.f. $>90$ years & D1R & 90 \\
\hline \multirow[t]{3}{*}{ Bükk (g) } & Previous grazing/mowing & D1 & 94 \\
\hline & Previous grazing/mowing; previous lime kiln & $\mathrm{D} 2$ & 81 \\
\hline & $\begin{array}{l}\text { Previous grazing/mowing; previous lime kiln; plant invasion } \\
\text { (Calamagrostis epigejos) }\end{array}$ & D3 & 79 \\
\hline Bükk (gp) & Previous grazing/mowing & D1R & 90 \\
\hline Total & - & - & 1263 \\
\hline
\end{tabular}

$f$ forested dolines, $g$ non-forested dolines, $f p$ forests on plateaus, $g p$ grasslands on plateaus, $a . f$. age of forest 
developed under the highest disturbance levels (see Table 1). 'Dolines with medium disturbance' (class D2) represent intermediate disturbance levels. Although we used the same disturbance classes across the sites, disturbances were site specific and therefore comparisons of disturbance classes across sites were not possible.

Since the number of non-forested dolines was very limited within the study sites in Kras and Mecsek, only forested dolines were considered, while in Bükk both forested and nonforested dolines were investigated. We selected three larger dolines from each disturbance class (D1, D2 and D3) at each site for vegetation sampling, except at the forested site in Bükk, where only two groups (D1 and D2) could be distinguished. For reference, we also selected three plateaus with little disturbance (D1R) at each site. The morphological features (diameter and depth) of dolines were similar within a study site (Table E1 in Supplementary materials). A total of 33 dolines (24 forested and 9 non-forested) and 12 plateaus ( 9 forested and 3 non-forested) were sampled.

Because the greatest differences in species composition were expected between the north- and south-facing doline slopes (Bátori et al. 2012, 2014b), we established a transect with north to south orientation across each doline, traversing their deepest point (Fig. 1b). Transects began and ended on doline rims, their length varied between 37 and $127 \mathrm{~m}$. For reference, a 89-m-long transect was established on each plateau. Transects consisted of $1 \times 1 \mathrm{~m}$ plots spaced at $2 \mathrm{~m}$ intervals (1263 plots in total: 903 in dolines and 360 on plateaus). We recorded the presence/absence of all shrubs and herbs in each plot. Fieldwork was carried out in May in Kras, in June to August in Mecsek, and in July and August in Bükk, at the peak of the growing season. Nomenclature follows 'The Plant List' (www. theplantlist.org).

\section{Species grouping}

Although Ellenberg indicator values for temperature are frequently used to compare the temperature characteristics of different habitats in a larger biogeographical scale, they often fail to capture local-scale changes in habitats (Borhidi 1995). Therefore, we used the habitat preferences of plant species instead of their temperature indicator values to define cool-adapted species and to compare the number of these species among the different disturbance classes. We classified all plant species according to their habitat preferences following the system of Soó (1980) for Hungary and the system of Mucina et al. (2016) for Slovenia. Cool-adapted species were defined for each study site separately. In this study we used the term 'cool-adapted plant' for plants that usually occur in habitats where the climate is cooler than that in the habitats of the plateaus between dolines. The group of cool-adapted species includes species of mesic deciduous, beech and ravine forests in Kras, species of beech and ravine forests in Mecsek, species of montane beech, ravine and coniferous forests at the forested site in Bükk, and species of fens, montane grasslands, ravine and montane beech forests at the non-forested site in Bükk (Table E2 in Supplementary materials). Moist-adapted species were defined using the Ellenberg indicator values for moisture [Borhidi (1995) for Hungary and Pignatti (2005) for Slovenia], which are often applied to characterise habitats at various biogeographical scales. In this study we used the term 'moist-adapted plant' for plants that have an indicator value of 6,7 or 8 for moisture in Kras and Mecsek, and 7, 8 or 9 in Bükk (i.e. the three highest indicator values for moisture within a site) (Table E3 in Supplementary materials). Species of high conservation 
importance (i.e. protected and/or red-listed species) were defined according to regional lists (Slovenia: www.pisrs.si; Hungary: Király 2007) (Table E4 in Supplementary materials).

\section{Statistical analyses}

We tested for differences between habitats, i.e., little disturbed dolines (D1) versus little disturbed plateau (D1R), and differences among disturbance classes (D1, D2 and D3) for each site separately. Diagnostic species for the different habitats and disturbance classes were determined by calculating the fidelity measure phi $(\Phi)$, a coefficient of association between species and habitat, using the JUICE program (Tichý 2002). Species with $\Phi \times 100>20.0$ were considered diagnostic (Fisher's exact test, $p<0.001$ ) (Tichý and Chytry 2006).

We used one-way analysis of similarities (ANOSIM) to compare the species composition between habitats and among disturbance classes. We used the raw presence/absence data of species for each sampling plot in the source matrices. We applied the Jaccard dissimilarity and performed 9999 permutations. ANOSIMSs were calculated in R (R Core Team 2018) using the anosim function of the 'vegan' package (Oksanen 2018). The $p$ values in pairwise comparisons were Bonferroni corrected. We used principal coordinates analyses (PCoA, Jaccard index) to illustrate any compositional differences.

We used bar charts to illustrate the number of cool-adapted, moist-adapted and highconservation-importance species in different habitats and disturbance classes. To test if these differences were significant we used generalized linear mixed-effects models (GLMMs). Six models were built for each site to compare the number of cool-adapted, moist-adapted and high-conservation-importance species for both habitats (D1 and D1R) and disturbance classes (D1, D2 and D3). The number of cool-adapted, moist-adapted or high-conservation-importance species was the response variable, the habitat or disturbance class was treated as a fixed factor, and the transect surveyed was included as a random factor. We used Poisson or, if overdispersion was detected, negative binomial error term. Since the number of species of high conservation importance was one or zero in most plots of Mecsek (leading to zero inflation of the data), we transformed the data of species to binary scale (presence/absence) and used binomial error term. GLMMs were prepared in R using the glmer function of the 'Ime4' package (Bates et al. 2013). Full models were tested for significance with analysis of variance, using the Anova function of the 'car' package (Fox and Weisberg 2011). Pairwise comparisons of the factor levels were assisted with the relevel function and the FDR method (p.adjust function) was used to correct the $p$ values for multiple comparisons.

\section{Results}

A total of 383 plant species were recorded in the 1263 plots; 119 were found in Kras (61 in D1, 75 in D2, 70 in D3, and 51 in D1R), 78 in Mecsek (42 in D1, 49 in D2, 24 in D3, and 49 in D1R), 126 at the forested site in Bükk (36 in D1, 105 in D2, and 61 in D1R) and 229 at the non-forested site in Bükk (127 in D1, 145 in D2, 120 in D3, and 143 in D1R). The average number of species $(\mathrm{N} \pm \mathrm{SE})$ found per plot was $8.5 \pm 0.4$ in $\mathrm{D} 1,8.1 \pm 0.4$ in $\mathrm{D} 2$, 
$7.8 \pm 0.4$ in D3 and $6.0 \pm 0.2$ in D1R in Kras, $5.6 \pm 0.3$ in D1, 3.9 \pm 0.2 in D2, $2.2 \pm 0.2$ in D3 and 5.8 \pm 0.2 in D1R in Mecsek, $5.7 \pm 0.3$ in D1, 12.3 \pm 0.5 in D2 and 7.3 \pm 0.3 in D1R at the forested site in Bükk, and 15.8 \pm 0.7 in D1, 20.2 \pm 0.5 in D2, 14.0 \pm 0.7 in D3 and $20.1 \pm 0.5$ in D1R at the non-forested site in Bükk.

Fifteen diagnostic species differentiated between little disturbed habitats in dolines (D1) and on the plateau (D1R) in Kras, 9 in Mecsek, 9 at the forested site in Bükk and 32 at the non-forested site in Bükk. For disturbance classes (D1, D2 and D3), 6 diagnostic species were identified in Kras, 10 in Mecsek, 21 at the forested site in Bükk and 54 at the non-forested site in Bükk (Tables 2, 3, 4, 5). All diagnostic species of the dolines in Kras were cool- and/or moist-adapted species or had high conservation importance, but these three groups of species were absent from the plateau (D1R). In Mecsek, all diagnostic species of D1 were cool- and/or moist-adapted species, but only one cool-adapted species was identified for D1R and D2. D3 had only one diagnostic species. More diagnostic species were identified for D1 than for D1R at the forested site in Bükk. However, D2 had more diagnostic species than D1. A relatively high number

Table 2 List of diagnostic species for little disturbed dolines (D1) and the plateau (D1R) and for the different disturbance classes of dolines (D1: little, D2: medium and D3: high disturbance) in Kras (Slovenia)

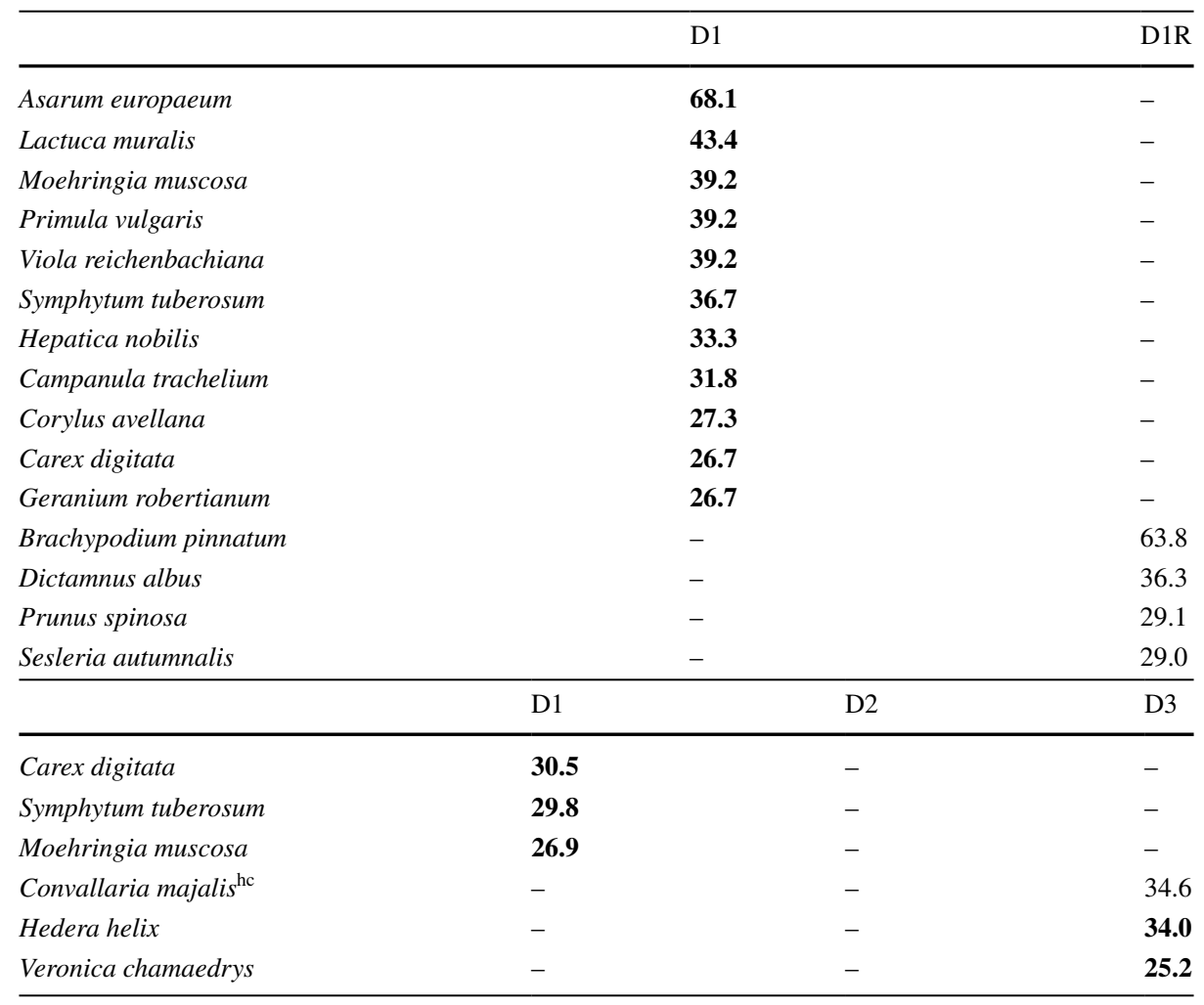

Within blocks, species are listed by decreasing values of the phi $(\Phi)$ coefficient of association between species and habitat. Fidelity values $(\Phi \times 100)$ of cool- and/or moist-adapted species are indicated with boldface. Non-diagnostic species were excluded with Fisher's exact test $(p<0.001)$

$h c$ species of high conservation importance 
Table 3 List of diagnostic species for little disturbed dolines (D1) and the plateau (D1R) and for the different disturbance classes of dolines (D1: little, D2: medium and D3: high disturbance) in Mecsek (Hungary)

\begin{tabular}{|c|c|c|c|}
\hline & \multicolumn{2}{|c|}{ D1 } & D1R \\
\hline Lamium galeobdolon s.1. & \multicolumn{2}{|c|}{52.3} & - \\
\hline Mercurialis perennis & \multicolumn{2}{|c|}{48.0} & - \\
\hline Pulmonaria officinalis & \multicolumn{2}{|c|}{27.8} & - \\
\hline Veronica montana & \multicolumn{2}{|c|}{26.8} & - \\
\hline Melica uniflora & \multicolumn{2}{|c|}{-} & 67.9 \\
\hline Stellaria holostea & \multicolumn{2}{|c|}{-} & 45.5 \\
\hline Carex pilosa & \multicolumn{2}{|c|}{-} & 36.6 \\
\hline Dactylis glomerata & \multicolumn{2}{|c|}{-} & 34.5 \\
\hline \multirow[t]{2}{*}{ Alliaria petiolata } & \multicolumn{2}{|c|}{-} & 23.6 \\
\hline & D1 & D2 & D3 \\
\hline Mercurialis perennis & 66.0 & - & - \\
\hline Hepatica nobilis ${ }^{\text {hc }}$ & 35.5 & - & - \\
\hline Galium odoratum & 34.0 & - & - \\
\hline Lamium galeobdolon s.1. & 31.9 & - & - \\
\hline Pulmonaria officinalis & 22.9 & - & - \\
\hline Chrysosplenium alternifolium & 21.7 & - & - \\
\hline Rubus proiectus agg. & - & 34.9 & - \\
\hline Carex pilosa & - & 21.9 & - \\
\hline Melica uniflora & - & 21.4 & - \\
\hline Hedera helix & - & - & 22.9 \\
\hline
\end{tabular}

Within blocks, species are listed by decreasing values of the phi $(\Phi)$ coefficient of association between species and habitat. Fidelity values $(\Phi \times 100)$ of cool- and/or moist-adapted species are indicated with boldface. Non-diagnostic species were excluded with Fisher's exact test $(p<0.001)$

$h c$ species of high conservation importance

of diagnostic species of D1 and D2 were cool- and/or moist-adapted species or had high conservation importance. Although more diagnostic species were identified for D1R than for D1 at the non-forested site in Bükk, none of them were cool- or moist-adapted species or species with high conservation importance. The number of such diagnostic species was the highest in D1. D3 had the lowest number of diagnostic species.

The plots from little disturbed dolines (D1) and the plateau (D1R) were separated based on species composition along the PCoA axis 1 for all sites (Fig. 2), and plots belonging to these two habitats were significantly different (ANOSIM, $0.23<\mathrm{R}<0.45, p<0.001$ ) (Table E5 in Supplementary materials). Dolines with different disturbance classes (D1, D2 and D3) also differed $(0.08<\mathrm{R}<0.52, p<0.001)$ in their species composition (Fig. 2), but not between D2 and D3 in Kras $(\mathrm{R}=0.02, p=0.22)$.

The number of cool-adapted species was significantly higher for little disturbed dolines (D1) than the plateau (D1R) for all sites $(-6.60 \leq \mathrm{z} \leq-2.39, p<0.05)$, except for the forested site in Bükk $(\mathrm{z}=0.05, p=0.960)$ (Fig. 3). Overall, no consistent differences for the number of cool-adapted species were observed among the different 
Table 4 List of diagnostic species for little disturbed dolines (D1) and the plateau (D1R) and for the different disturbance classes of dolines (D1: little and D2: medium disturbance) at the forested site in Bükk (Hungary)

\begin{tabular}{|c|c|c|}
\hline & D1 & D1R \\
\hline Impatiens noli-tangere & 50.9 & - \\
\hline Urtica dioica & 33.1 & - \\
\hline Circaea lutetiana & 27.3 & - \\
\hline Lunaria rediviva $^{\mathrm{hc}}$ & 27.1 & - \\
\hline Anthriscus nitida ${ }^{\text {hc }}$ & 26.1 & - \\
\hline Viola reichenbachiana & - & 43.3 \\
\hline Oxalis acetosella & - & 43.2 \\
\hline Stellaria holostea & - & 42.6 \\
\hline \multirow[t]{2}{*}{ Lactuca muralis } & - & 36.8 \\
\hline & D1 & D2 \\
\hline Sanicula europaea & 35.4 & - \\
\hline Galium odoratum & 35.1 & - \\
\hline Circaea lutetiana & 32.8 & - \\
\hline Lunaria rediviva ${ }^{\mathrm{hc}}$ & 29.1 & - \\
\hline Anthriscus nitida ${ }^{\mathrm{hc}}$ & 26.2 & - \\
\hline Lamium galeobdolon s.1. & 25.5 & - \\
\hline Milium effusum & - & 62.9 \\
\hline Oxalis acetosella & - & 45.7 \\
\hline Rubus idaeus & - & 44.0 \\
\hline Lonicera xylosteum & - & 39.6 \\
\hline Ajuga reptans & - & 35.5 \\
\hline Elymus caninus & - & 33.2 \\
\hline Dryopteris carthusiana ${ }^{\mathrm{hc}}$ & - & 32.8 \\
\hline Senecio ovatus & - & 32.2 \\
\hline Fragaria vesca & - & 31.0 \\
\hline Asarum europaeum & - & 30.6 \\
\hline Cruciata glabra & - & 29.3 \\
\hline Stellaria holostea & - & 29.0 \\
\hline Lactuca muralis & - & 26.9 \\
\hline Ribes uva-crispa & - & 25.0 \\
\hline Chrysosplenium alternifolium & - & 24.6 \\
\hline
\end{tabular}

Within blocks, species are listed by decreasing values of the phi $(\Phi)$ coefficient of association between species and habitat. Fidelity values $(\Phi \times 100)$ of cool- and/or moist-adapted species are indicated with boldface. Non-diagnostic species were excluded with Fisher's exact test $(p<0.001)$

$h c$ species of high conservation importance

disturbance classes (Fig. 3; Table E6 in Supplementary materials). However, in Mecsek, D1 contained significantly more cool-adapted species than D2 $(\mathrm{z}=-3.38, p<0.001)$ and D3 ( $\mathrm{z}=-6.90, p<0.001)$, and differences between D2 and D3 were also significant 
Table 5 List of diagnostic species for little disturbed dolines (D1) and the plateau (D1R) and for the different disturbance classes of dolines (D1: little, D2: medium and D3: high disturbance) at the non-forested site in Bükk (Hungary)

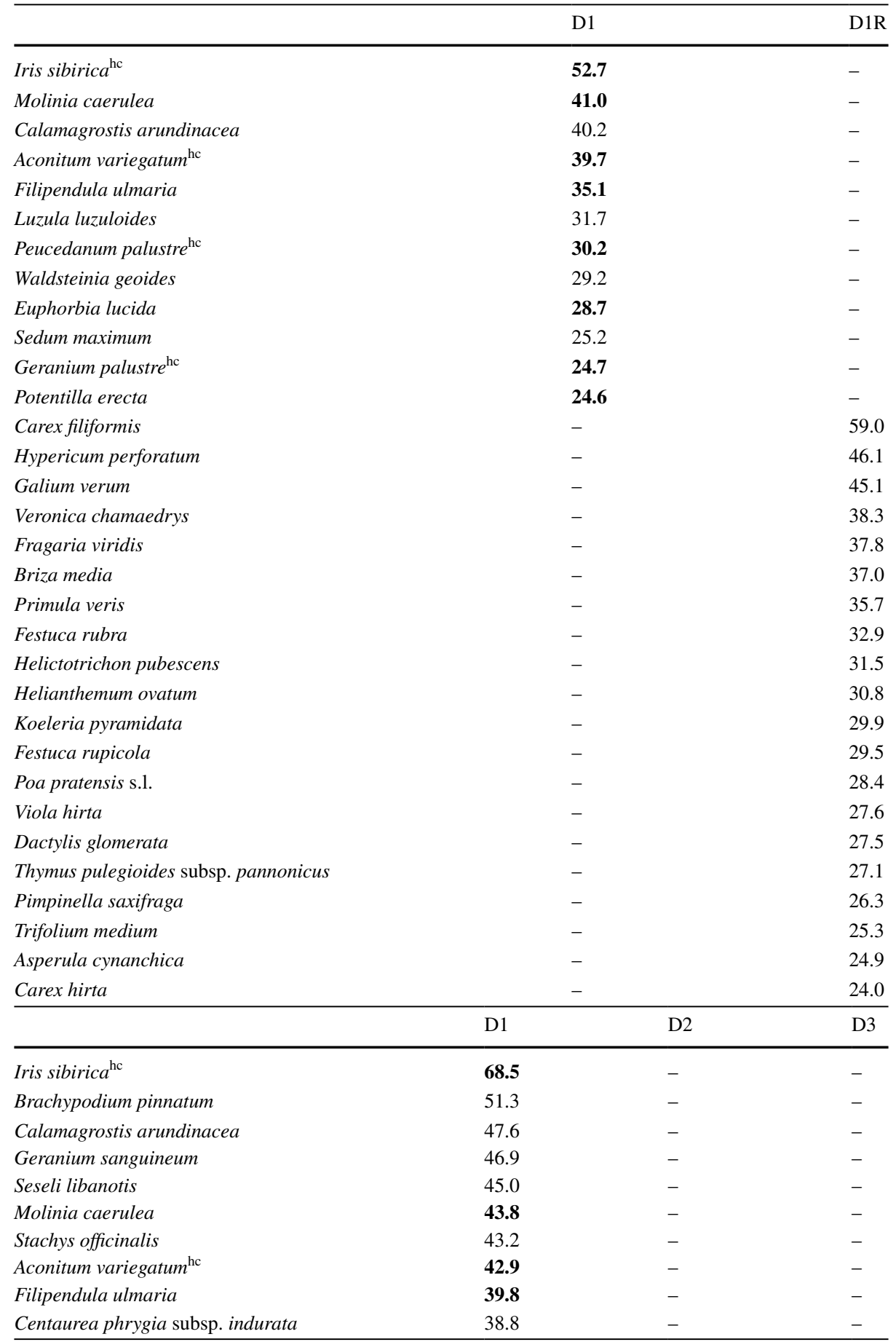


Table 5 (continued)

\begin{tabular}{|c|c|c|c|}
\hline & D1 & D2 & D3 \\
\hline Filipendula vulgaris & 33.3 & - & - \\
\hline Waldsteinia geoides & 33.3 & - & - \\
\hline Iris variegata $^{\mathrm{hc}}$ & 32.1 & - & - \\
\hline Peucedanum palustre ${ }^{\mathrm{hc}}$ & 32.0 & - & - \\
\hline Euphorbia lucida & 31.6 & - & - \\
\hline Luzula luzuloides & 29.7 & - & - \\
\hline Stellaria graminea & 28.4 & - & - \\
\hline Helictotrichon alpinum & 27.4 & - & - \\
\hline Anemone sylvestris ${ }^{\mathrm{hc}}$ & 26.9 & - & - \\
\hline Primula elatior he & 25.5 & - & - \\
\hline Cirsium pannonicum & 24.6 & - & - \\
\hline Carex divulsa & 24.4 & - & - \\
\hline Geranium palustre ${ }^{\mathrm{hc}}$ & 23.3 & - & - \\
\hline Centaurea scabiosa subsp. sadleriana ${ }^{\text {hc }}$ & 22.8 & - & - \\
\hline Succisa pratensis & 22.4 & - & - \\
\hline Sedum maximum & 21.7 & - & - \\
\hline Pimpinella saxifraga & - & 55.5 & - \\
\hline Hypericum perforatum & - & 48.1 & - \\
\hline Allium scorodoprasum & - & 44.8 & - \\
\hline Poa pratensis s.1. & - & 39.1 & - \\
\hline Vicia sepium & - & 38.4 & - \\
\hline Dactylis glomerata & - & 37.2 & - \\
\hline Achillea collina & - & 35.2 & - \\
\hline Carex pallescens & - & 31.5 & - \\
\hline Festuca pratensis & - & 29.6 & - \\
\hline Carex filiformis & - & 29.4 & - \\
\hline Alchemilla monticola ${ }^{\mathrm{hc}}$ & - & 28.4 & - \\
\hline Rumex acetosa & - & 28.2 & - \\
\hline Trifolium medium & - & 27.5 & - \\
\hline Convolvulus arvensis & - & 26.5 & - \\
\hline Ranunculus polyanthemos & - & 25.0 & - \\
\hline Galium boreale & - & 24.2 & - \\
\hline Hypochaeris maculata & - & 24.2 & - \\
\hline Potentilla erecta & - & 23.9 & - \\
\hline Galium verum & - & 23.1 & - \\
\hline Cirsium eriophorum & - & 23.0 & - \\
\hline Lotus corniculatus & - & 22.2 & - \\
\hline Calamagrostis epigejos & - & - & 72.1 \\
\hline Bromus erectus & - & - & 32.4 \\
\hline Rhamnus cathartica & - & - & 31.8 \\
\hline Cardamine pratensis & - & - & 29.5 \\
\hline Euphorbia salicifolia & - & - & 29.5 \\
\hline Sanguisorba minor & - & - & 27.5 \\
\hline Vicia sativa subsp. nigra & - & - & 26.2 \\
\hline
\end{tabular}

Within blocks, species are listed by decreasing values of the phi $(\Phi)$ coefficient of association between species and habitat. Fidelity values $(\Phi \times 100)$ of cool- and/or moist-adapted species are indicated with boldface. Non-diagnostic species were excluded with Fisher's exact test $(p<0.001)$

$h c$ species of high conservation importance 

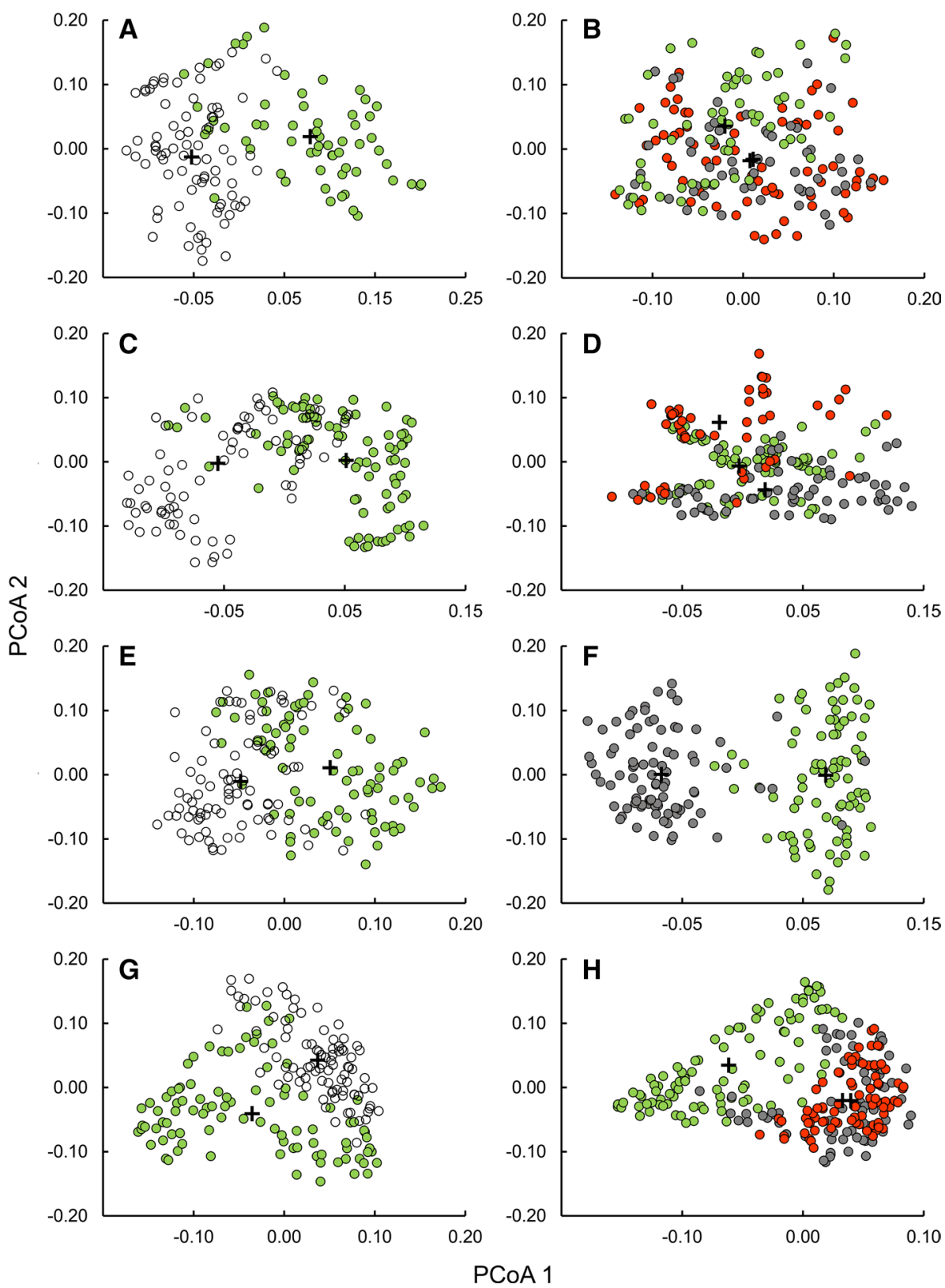

Fig. 2 Principal coordinates analysis (PCoA) for the plots in Kras (a, b), Mecsek (c, d), forested site in Bükk (e, f) and non-forested site in Bükk $(\mathbf{g}, \mathbf{h})$. Colours indicate the disturbance classes of dolines (green: D1, little disturbance; grey: D2, medium disturbance, and red: D3, high disturbance) and plateaus (white: D1R, little disturbance). Crosses indicate centroid of each class. The first two eigenvalues explained $22.1 \%$ (a) and $15.2 \%$ (b) of the variance in the data set in Kras, 29.1\% (c) and 25.4\% (d) in Mecsek, $17.2 \%$ (e) and $20.2 \%$ (f) at the forested site in Bükk, and $19.6 \%$ (g) and $16.5 \%$ (h) at the non-forested site in Bükk 
Fig. 3 Occurrences of cool-adapted (a-d) and moist-adapted (e-h) plant species (mean \pm SE) in the plots of dolines (D1: little, D2: medium and D3: high disturbance) and plateaus (D1R: little disturbance) in Kras (a, e), Mecsek (b, f), at the forested site in Bükk $(\mathbf{c}, \mathbf{g})$ and non-forested site in Bükk $(\mathbf{d}, \mathbf{h})$. Significant differences (between D1R and D1, and between D1, D2 and D3) detected using mixed-effect models (see Tables E6 and E7 in Supplementary materials) are indicated by asterisks $\left({ }^{*} p<0.05\right.$, $* * p<0.01$; and $\left.* * * p<0.001\right)$ and different lower case letters $(\mathrm{a}-\mathrm{c}, p<0.05)$, respectively. n.s. non-significant

$(\mathrm{z}=-3.68, p<0.001)$. At the forested site in Bükk, D2 had significantly more cooladapted species than D1 $(\mathrm{z}=-2.35, p<0.05)$. At the non-forested site in Bükk, D1 and D2 contained more cool-adapted species than D3 $(\mathrm{z}=-2.89, p<0.01$, and $\mathrm{z}=-2.35$, $p<0.05$, respectively). Although the sets of cool- and moist-adapted species differed considerably (Tables E2 and E3 in Supplementary materials), these two sets displayed very similar patterns of species richness with regard to disturbance classes (Fig. 3) the key difference being that there was a significantly higher number of species in D1 than in D1R $(\mathrm{z}=-3.01, p<0.01)$ for moist-adapted species at the forested site in Bükk (Table E7 in Supplementary materials).

Little disturbed dolines (D1) on average had more species of high conservation importance than the plateau (D1R) for all sites (Fig. 4; Table E8 in Supplementary materials). However, these differences were only significant for the non-forested site in Bükk $(\mathrm{z}=-2.99, p<0.01)$. This site was also the only site to display significant differences between disturbance classes, with D1 having significantly more species of high conservation importance than D2 $(\mathrm{z}=-1.95, p=0.05)$ and D3 $(\mathrm{z}=-4.03, p<0.001)$, and D2 having significantly more species than $\mathrm{D} 3(\mathrm{z}=-2.13, p<0.05)$.

\section{Discussion}

Dolines have the capacity to maintain the populations of vulnerable plant species and thus may function as safe havens or microrefugia during environmental changes, highlighting their importance for conservation. We further demonstrated that anthropogenic disturbances play a significant role in determining the composition and diversity of plant species in dolines. While anthropogenic disturbance generally reduced the number of cool-adapted, moist-adapted and high-conservation-importance species, we documented that one type of human disturbance, the planting of Picea abies (in Bükk), increased the number of cooladapted and moist-adapted species supported in dolines. This highlights that management for conservation needs to consider the different impacts of various disturbances. Below we further elaborate on the implications of these key findings.

Our findings lend further support to dolines providing unique habitats in karst landscapes that have distinct species composition compared to the surrounding plateau (Bátori et al. 2009, 2017). A number of studies indicate that dolines have the capacity to act as safe havens for plants with high conservation value (e.g., species listed in the IUCN regional and/or global Red Lists). Notable examples include Biebersteinia orphanidis (Greece, Yannitsaros and Constantinidis 1996), Cerastium dinaricum (Slovenia, Wraber 1995), Dracocephalum ruyschiana (Hungary and Serbia, Lazarević et al. 2009) and Horstrissea dolinicola (Greece, Egli et al. 1990). We found that little disturbed dolines (D1) may contain more plants of high conservation importance than the surrounding plateau (D1R), 

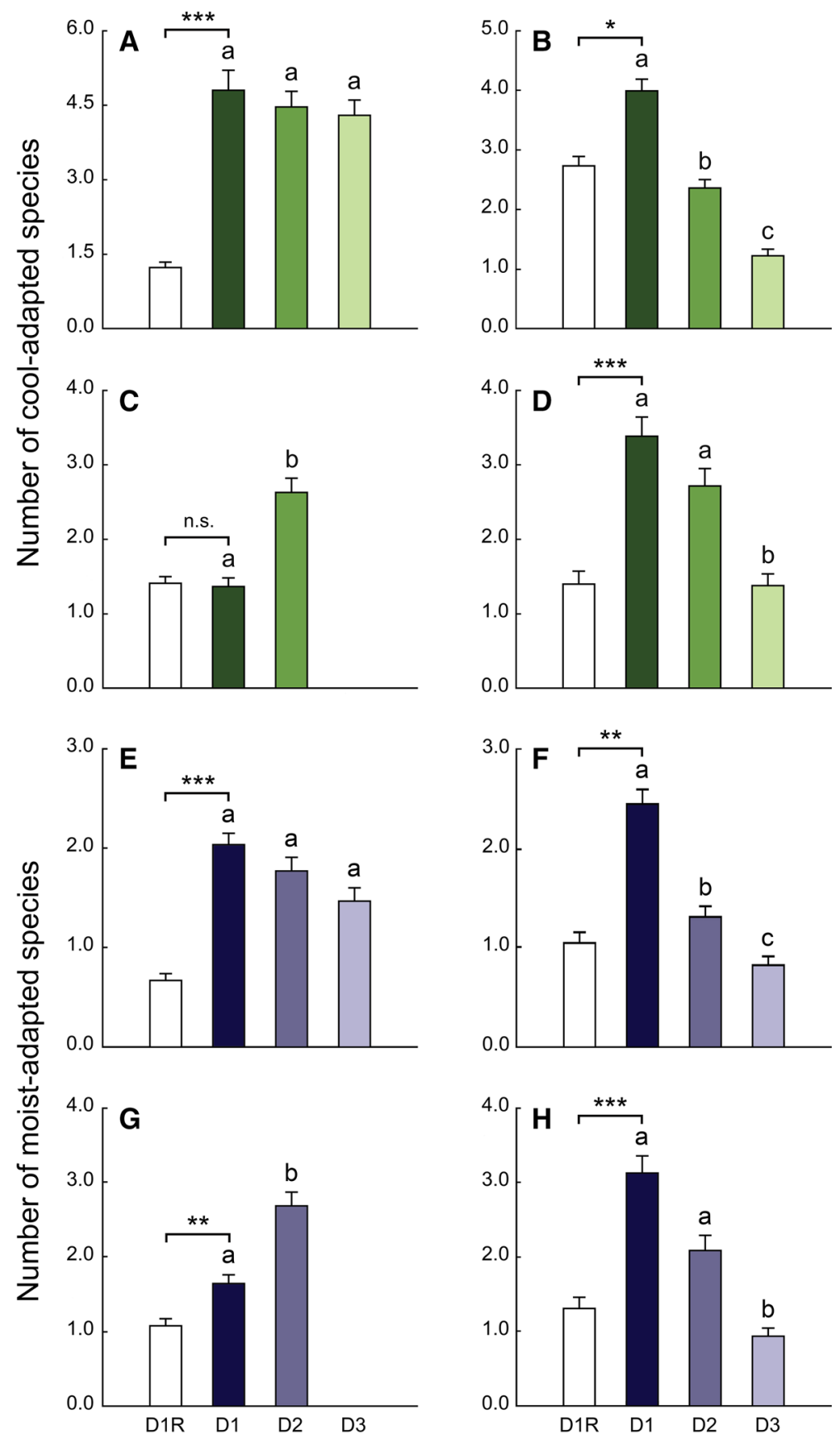

Types of disturbance 


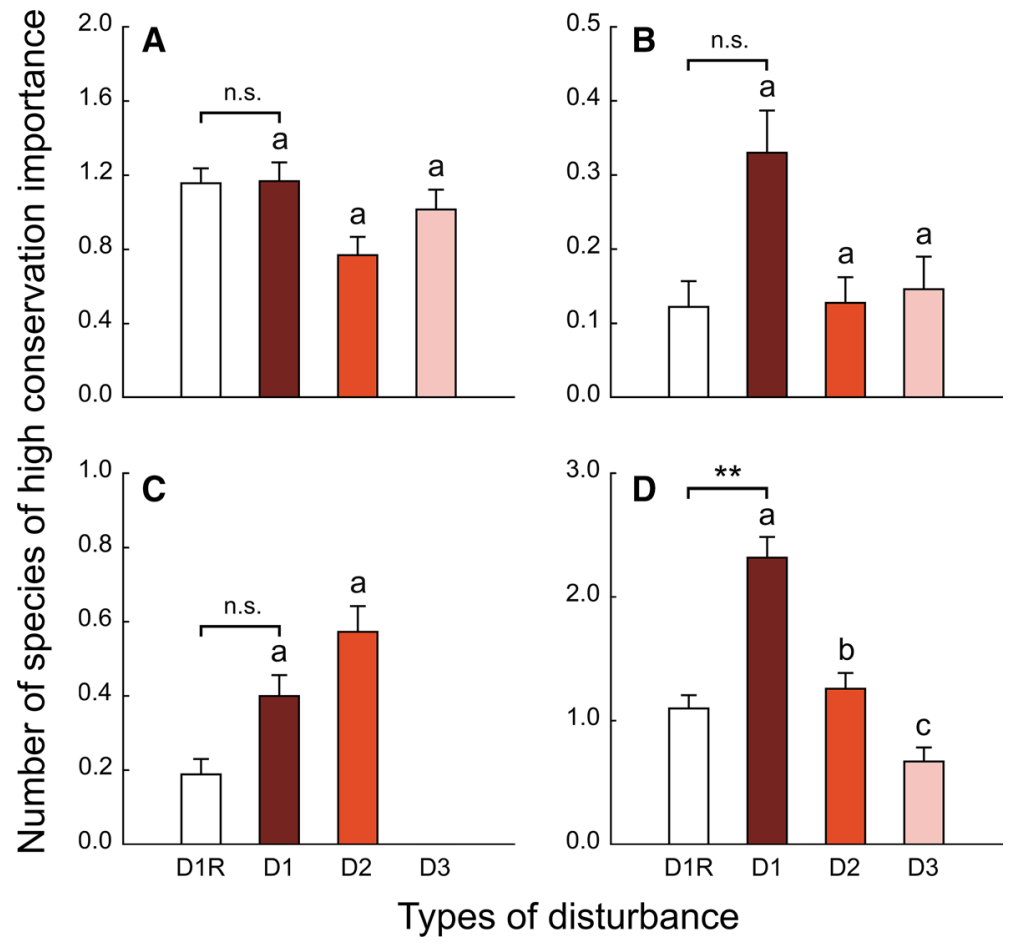

Fig. 4 Occurrences of plant species of high conservation importance (mean $\pm \mathrm{SE}$ ) in the plots of dolines (D1: little, D2: medium and D3: high disturbance) and plateaus (D1R: little disturbance) in Kras (a), Mecsek (b), at the forested site in Bükk (c) and non-forested site in Bükk (d). Significant differences (between D1R and D1, and between D1, D2 and D3) detected using mixed-effect models (see Table E8 in Supplementary materials) are indicated by asterisks $(* * p<0.01)$ and different lower case letters $(\mathrm{a}-\mathrm{c}, p \leq 0.05)$, respectively. n.s. non-significant

especially in grassland ecosystems (Fig. 4; Table 5). This is likely due to dolines providing diverse microhabitats (e.g., south- and north-facing slopes) with little spatial separation (Özkan et al. 2010).

Of particular importance in the face of global warming is that dolines have the capacity to support cool-adapted species that cannot be sustained on the surrounding plateau, lending support to their role as microrefugia (Bátori et al. 2017). The ability to support peripheral and relict populations of cool-adapted species (most of these species are redlisted and/or protected; Vojtkó 2001; Růžička et al. 2016; Bátori et al. 2017) is likely related to shaded, cooler north-facing slopes and shaded doline bottoms with cool air pooling (Bárány-Kevei 1999; Bátori et al. 2019), habitat types that have been demonstrated to experience less changes in temperature under global warming (Suggitt et al. 2011; Maclean et al. 2017; Greiser et al. 2018). Other studies also reported that higher microhabitat diversity can support a higher diversity of species of high conservation value, such as endemic and relict plants (Wezel 2007; Keppel et al. 2017; Suggit et al. 2018; Filibeck et al. 2019).

Macroclimate, topography and vegetation cover are significant predictors of the diversity of cool-adapted plants in dolines (Favretto and Poldini 1985; Bátori et al. 
2014a, 2017; Vojtkó et al. 2018). At warmer sites, the distribution of these plants is usually restricted to the deeper parts of dolines (where the microclimate is cooler), and non-forested dolines usually contain more cool-adapted plants than the neighbouring forested ones (Bátori et al. 2012, 2017). We found that at the warmest site (Kras) little disturbed dolines (D1) contained about 4 times more cool-adapted plants than surrounding plateaus (D1R), while at the coldest site (forested site in Bükk) the difference between D1 and D1R was negligible (Fig. 3). This difference was intermediate in Mecsek and at the non-forested site in Bükk, with about 1.5 and 2.5 times more cooladapted plants in D1 than in D1R. Our results correspond well with those for Europe in general, where decoupling from regional environmental factors (e.g., temperature, moisture and soil) provided by local depressions plays a key role in the maintenance of trailing edge populations (Tan et al. 1997; Antonić et al. 2001; Růžička et al. 2016; Bátori et al. 2017; Bauer 2018). They also highlight the importance of other microhabitats, such as ravines, valleys and north-facing slopes, where topographic features create yearround stable microclimatic conditions (Ashcroft et al. 2008; Dobrowski 2010; Lenoir et al. 2017).

Historic anthropogenic disturbances had considerable impacts on the species composition and the amount of vulnerable species in dolines (Figs. 2, 3, 4). Generally, disturbances reduced the number of species that are cool-adapted, moist-adapted and of high conservation importance, reducing the conservation value of dolines. Several other studies have highlighted that climatically diverse habitats are extremely sensitive to anthropogenic disturbances and that their recovery from such disturbances may be slow or incomplete (Stylinski and Allen 1999; Lindenmayer et al. 2017; Breg Valjavec et al. 2018b). We found that stronger disturbances that have a significant effect on the vegetation structure, such as intensive logging and invasion by Calamagrostis epigejos, can lead to significant declines of cool-adapted, moist-adapted and high-conservation importance plant species in dolines (Figs. 2, 3, 4; Tables 3 and 5). Therefore, these disturbances seem to decrease the capacity of dolines to support vulnerable species and their potential to function as long-term microrefugia. This reduction in the conservation value of the dolines could be caused by changes to biotic (e.g., reduced species diversity and altered ecological interactions) and abiotic (e.g., altered light availability, moisture and temperature) characteristics (cf. Somodi et al. 2008; Házi et al. 2011; Kovács et al. 2017; Hu et al. 2018).

However, a detrimental impact on species that are cool-adapted, moist-adapted and of high conservation importance was not always observed (Figs. 3, 4). In Kras, we did not find any differences in the number of cool-adapted and moist-adapted species among the different disturbance classes (D1, D2 and D3), possibly because the addition of soil to the bottom of these dolines (D2 and D3) provides more favourable sites with much deeper and moister soils than on the plateaus (Kovačič and Ravbar 2013; Breg Valjavec et al. 2018a), resulting in rapid ( $<50$ years) recovery from disturbance for both cool-adapted and moistadapted species.

In Bükk, dolines with old Norway spruce plantations (D2) had a higher number of cooladapted and moist-adapted species than sites with little disturbance (D1) (Fig. 3). Norway spruce formed a dense, evergreen canopy in these dolines, likely creating unique microclimates. In addition, spruce produces more acidic litter and forest floors (Binkley and Valentine 1991; Cruz-Paredes et al. 2019), contributing to the persistence of some acidophilic plant species (e.g., Dryopteris dilatata and Moneses uniflora) that usually occur at higher elevations than Bükk. These results are in line with other studies that demonstrated the 
potential of plantation forests to maintain the populations of valuable species (Sutton 1999; Brockerhoff et al. 2008). They also highlighted that there is an urgent need to improve our understanding about the effects of disturbance and ecosystem characteristics (e.g., duration and intensity of disturbance, resilience and resistance of ecosystem functions, and recovery time) on the local and regional species composition and diversity (O'Brien et al. 2018; van de Leemput et al. 2018; Kermavnar et al. 2019).

Diversity patterns for species of high conservation importance mostly mirrored those for cool-adapted species between the two different habitats (D1 and D1R) and among the different disturbance classes (D1, D2 and D3). This is due to considerable overlap between the two groups of species, with more than $63 \%$ of all taxa of high conservation importance also being cool-adapted species (see Tables 2, 3, 4, 5; Tables E2 and E4 in Supplementary materials). This is not surprising given that many of the species in the study region are threatened due to continuously warming climates since the last glacial maximum (cf. Vojtkó 2001; Király 2009; Bátori et al. 2017). However, we obtained less significant results for species of high conservation importance than for cool-adapted and moist-adapted species, partially because the number of species of high conservation importance was generally low (Figs. 3, 4).

Global warming is predicted to continue driving range shifts of the main vegetation zones in Europe, with many cool-adapted and moist-adapted species likely to disappear from lower elevations (Walther et al. 2002; Chen et al. 2011; Lamprecht et al. 2018). Based on their past and current ability to facilitate persistence, dolines are likely to provide important microrefugia, where these species can persist for a longer time than in the surrounding landscape (Bátori et al. 2017; Raschmanová et al. 2018). However, changes to the physical environment (e.g., microclimate, light availability and topography) by anthropogenic disturbances will alter the capacity of dolines to support vulnerable species by affecting recolonization, germination and growth of plant species (Zenner and Berger 2008). Our study shows that many disturbances, such as intensive logging, will reduce the capacity of dolines to facilitate the persistence of vulnerable species. Such disturbances should be reduced to increase the conservation value of dolines. However, other potential management practices intended to reverse past disturbances, such as the removal of planted Norway spruce from dolines, could adversely affect the value of dolines.

Therefore, careful consideration of the impacts of the various disturbances that have altered dolines in karst formations is required to maximise the resilience of these landscapes to future global warming. An integrated approach is required to provide solutions for adequate landscape management that ensures the retention of sufficient habitat for vulnerable species. For instance, the maintenance of mature forests and continuous forest cover in and around dolines and the suppression of undesirable species (e.g., Calamagrostis epigejos and Cirsium arvense) are expected to facilitate the long-term survival of cooladapted and moist-adapted species in a warming climate (cf. Frey et al. 2016). Our results also support the view that there is an urgent need to integrate disturbance responses and non-deterministic successional pathways into climate change modelling of species distributions (Syphard and Franklin 2010; Serra-Diaz et al. 2015).

Our study has illustrated that dolines have the capacity to function as habitat islands that facilitate the persistence of a high diversity of cool-adapted, moist-adapted and highconservation-importance plant species and that this capacity is strongly influenced by local anthropogenic disturbances (Fig. 5). Although anthropogenic disturbances generally decrease the conservation value of dolines, they can also increase the capacity of dolines to function as microrefugia for cool-adapted and moist-adapted species under global warming. Therefore, thorough understanding of the relationships between disturbances and 


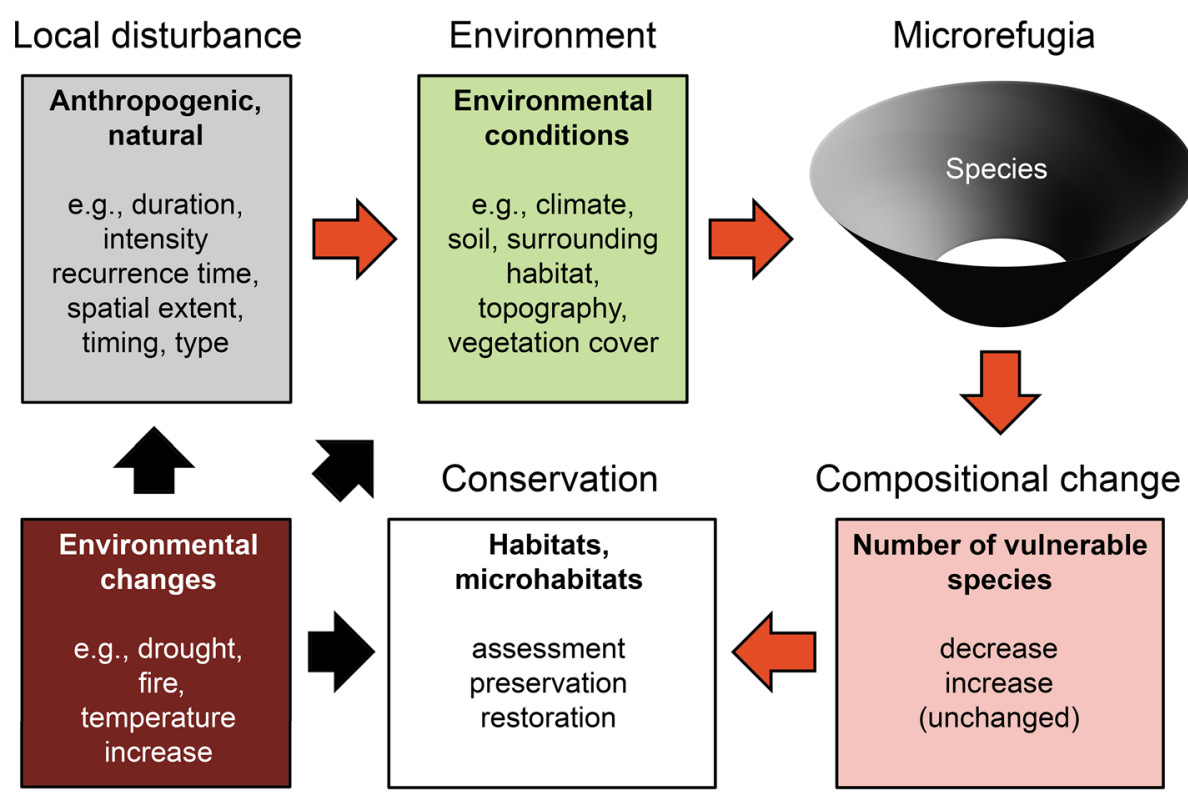

\section{Global warming}

Fig. 5 Environmental conditions, local disturbances and environmental changes affect the species composition of current and potential microrefugia in multiple ways. Determining the combined effects of these factors on the species composition of these microhabitats allows their protection and the selection of the most appropriate conservation strategies

species composition is necessary to successfully manage landscapes for the persistence of vulnerable species under global warming.

Acknowledgements Open access funding provided by University of Szeged (SZTE) (grant number: 4456). This research was supported by the NKFIH K 124796 grant. The authors acknowledge the financial support from the Slovenian Research Agency research core funding Geography of Slovenia (P6-0101) and Biodiversity: patterns, processes, predictions and conservation (P1-0236). We are thankful to Anna E Vojtkó and Imola Bóni for their help in field works. The permission of the Bükk National Park, Duna-Dráva National Park and Škocjan Caves Regional Park to carry out our field activities is also greatly acknowledged.

Open Access This article is distributed under the terms of the Creative Commons Attribution 4.0 International License (http://creativecommons.org/licenses/by/4.0/), which permits unrestricted use, distribution, and reproduction in any medium, provided you give appropriate credit to the original author(s) and the source, provide a link to the Creative Commons license, and indicate if changes were made.

\section{References}

Antonić O, Hatic D, Pernar R (2001) DEM-based depth in sink as an environmental estimator. Ecol Model 138:247-254

Ashcroft MB (2010) Identifying refugia from climate change. J Biogeogr 37:1407-1413

Ashcroft MB, Chisholm LA, French KO (2008) The effect of exposure on landscape scale soil surface temperatures and species distribution models. Landsc Ecol 23:211-225

Bárány-Kevei I (1999) Microclimate of karstic dolines. Acta Climatol Univ Szegediensis 32-33:19-27

Bates D, Maechler M, Bolker B (2013) lme4: linear mixedeffects models using S4 classes. R package version 0.999999-2. http://cran.r-project.org/package=lme4 
Bátori Z, Csiky J, Erdős L et al (2009) Vegetation of the dolines in Mecsek Mountains (South Hungary) in relation to the local plant communities. Acta Carsolog 38:237-252

Bátori Z, Körmöczi L, Erdős L et al (2012) Importance of karst sinkholes in preserving relict, mountain, and wet-woodland plant species under sub-Mediterranean climate: a case study from southern Hungary. J Cave Karst Stud 74:127-134

Bátori Z, Csiky J, Farkas T et al (2014a) The conservation value of karst dolines for vascular plants in woodland habitats of Hungary: refugia and climate change. Int J Speleol 43:15-26

Bátori Z, Farkas T, Erdős L et al (2014b) A comparison of the vegetation of forested and non-forested solution dolines in Hungary: a preliminary study. Biologia 69:1339-1348

Bátori Z, Vojtkó A, Farkas T et al (2017) Large- and small-scale environmental factors drive distributions of cool-adapted plants in karstic microrefugia. Ann Bot 119:301-309

Bátori Z, Vojtkó A, Maák IE et al (2019) Karst dolines provide diverse microhabitats for different functional groups in multiple phyla. Sci Rep 9:7176

Battisti C, Giardini M, Marini F et al (2017) Diversity metrics, species turnovers and nestedness of bird assemblages in a deep karst sinkhole. Isr J Ecol Evol 63:8-16

Bauer N (2018) Contributions and plant geographical notes to the flora of Cres-Lošinj archipelago (Croatia). Nat Croat 27:331-342

Berbet MLC, Costa MH (2003) Climate change after tropical deforestation: seasonal variability of surface albedo and its effects on precipitation change. J Clim 16:2099-2104

Binkley D, Valentine D (1991) Fifty-year biogeochemical effects of green ash, white pine, and Norway spruce in a replicated experiment. Forest Ecol Manag 40:13-25

Borhidi A (1995) Social behaviour types, the naturalness and relative indicator values of the higher plants in the Hungarian Flora. Acta Bot Hung 39:97-182

Breg Valjavec M (2014) Study of filled dolines by using 3D stereo image processing and electrical resistivity imaging. Int J Speleol 43:57-68

Breg Valjavec M, Zorn M, Čarni A (2018a) Bioindication of human-induced soil degradation in enclosed karst depressions (dolines) using Ellenberg indicator values (Classical Karst, Slovenia). Sci Total Environ 640-641:117-126

Breg Valjavec M, Zorn M, Čarni A (2018b) Human-induced land degradation and biodiversity of Classical Karst landscape: on the example of enclosed karst depressions (dolines). Land Degrad Dev 29:3823-3835

Brockerhoff EG, Jactel H, Parrotta JA et al (2008) Plantation forests and biodiversity: oxymoron or opportunity? Biodivers Conserv 17:925-951

Brullo S, Giusso del Galdo G (2001) Astracantha dolinicola (Fabaceae): a new species from Crete. Nord J Bot 21:475-480

Chauchard S, Carcaillet C, Guibal F (2007) Patterns of land-use abandonment control tree-recruitment and forest dynamics in Mediterranean mountains. Ecosystems 10:936-948

Chen IC, Hill JK, Ohlemüller R et al (2011) Rapid range shifts of species associated with high levels of climate warming. Science 333:1024-1026

Cruz-Paredes C, Frøslev TG, Michelsen A et al (2019) Wood ash application in a managed Norway spruce plantation did not affect ectomycorrhizal diversity or N retention capacity. Fungal Ecol 39:1-11

De Waele J (2009) Evaluating disturbance on mediterranean karst areas: the example of Sardinia (Italy). Environ Geol 58:239-255

Dobrowski SZ (2010) A climatic basis for microrefugia: the influence of terrain on climate. Glob Change Biol 17:1022-1035

Dövényi Z (ed) (2010) Magyarország kistájainak katasztere. MTA Földrajztudományi Kutatóintézet, Budapest

Egli BR (1991) The special flora, ecological and edaphic conditions of dolines in the mountain of Crete. Bot Chron 10:325-335

Egli BR, Gerstberger P, Greuter W et al (1990) Horstrissea dolinicola, a new genus and species of umbels (Umbelliferae, Apiaceae) from Kriti (Greece). Willdenowia 19:389-399

Favretto D, Poldini L (1985) The vegetation in the dolinas of the karst region near Trieste (Italy). Studia Geobotanica 5:5-18

Filibeck G, Sperandii MG, Bazzichetto M et al (2019) Exploring the drivers of vascular plant richness at very fine spatial scale in sub-Mediterranean limestone grasslands (Central Apennines, Italy). Biodivers Conserv 28:2701-2725

Fox J, Weisberg S (2011) An \{R\} Companion to applied regression, 2nd Edition. Sage, Thousand Oaks. http://socserv.socsci.mcmaster.ca/jfox/Books/Companion

Frey SJK, Hadley AS, Betts MG (2016) Microclimate predicts within-season distribution dynamics of montane forest birds. Divers Distrib 22:944-959 
Gibb H, Sanders NJ, Dunn RR et al (2018) Habitat disturbance selects against both small and large species across varying climates. Ecography 41:1184-1193

Greiser C, Meineri E, Luoto M et al (2018) Monthly microclimate models in a managed boreal forest landscape. Agr Forest Meteorol 250-251:147-158

Guariguata MR, Ostertag R (2001) Neotropical secondary forest succession: changes in structural and functional characteristics. Forest Ecol Manag 148:185-206

Guisan A, Thuiller W (2005) Predicting species distribution: offering more than simple habitat models. Ecol Lett 8:993-1009

Hampe A, Petit RJ (2005) Conserving biodiversity under climate change: the rear edge matters. Ecol Lett $8: 461-467$

Házi J, Bartha S, Szentes S et al (2011) Seminatural grassland management by mowing of Calamagrostis epigejos in Hungary. Plant Biosyst 145:699-707

Horvat I (1953) Vegetacija ponikava. Hrvatski. Geografski Glasnik 14-15:1-25

Hu J, Herbohn J, Chazdon RL et al (2018) Recovery of species composition over 46 years in a logged Australian tropical forest following different intensity silvicultural treatments. Forest Ecol Manag 409:660-666

Iatroú G, Fournaraki C (2006) Horstrissea dolinicola (errata version published in 2016). The IUCN Red List of Threatened Species 2006. http://www.iucnredlist.org/details/61613/0

Jian XM, Shui W, Wang YN et al (2018) Species diversity and stability of grassland plant community in heavily-degraded karst tiankeng: a case study of Zhanyi Tiankeng in Yunnan, China. Acta Ecol Sin 38:4704-4714

Kaligarič M, Culiberg M, Kramberger B (2006) Recent vegetation history of the North Adriatic grasslands: expansion and decay of an anthropogenic habitat. Folia Geobot 41:241-258

Kemencei Z, Farkas R, Páll-Gergely B et al (2014) Microhabitat associations of land snails in forested dolinas: implications for coarse filter conservation. Community Ecol 15:180-186

Keppel G, Wardell-Johnson GW (2015) Refugial capacity defines holdouts, microrefugia and steppingstones: a response to Hannah et al. Trends Ecol Evol 30:233-234

Keppel G, Mokany K, Wardell-Johnson GW et al (2015) The capacity of refugia for conservation planning under climate change. Front Ecol Environ 13:106-112

Keppel G, Robinson TP, Wardell-Johnson GW et al (2017) A low-altitude mountain range as an important refugium for two narrow endemics in the Southwest Australian Floristic Region biodiversity hotspot. Ann Bot 119:289-300

Kermavnar J, Eler K, Marinšek A et al (2019) Initial understory vegetation responses following different forest management intensities in Illyrian beech forests. Appl Veg Sci 22:48-60

Király G (ed) (2007) Vörös Lista. A magyarországi edényes flóra veszélyeztetett fajai, Saját kiadás

Király G (ed) (2009) Új magyar füvészkönyv. Magyarország hajtásos növényei, Határozókulcsok, Aggteleki Nemzeti Park Igazgatóság, Jósvafő

Kovačič G, Ravbar N (2013) Analysis of human induced changes in a karst landscape-the filling of dolines in the Kras plateau, Slovenia. Sci Total Environ 447:143-151

Kovács B, Tinya F, Ódor P (2017) Stand structural drivers of microclimate in mature temperate mixed forests. Agr Forest Meteorol 234:11-21

Lamprecht A, Semenchuk PR, Steinbauer K et al (2018) Climate change leads to accelerated transformation of high-elevation vegetation in the central Alps. New Phytol 220:447-459

Lazarević P, Lazarević M, Krivošej Z et al (2009) On the distribution of Dracocephalum ruyschiana (Lamiaceae) in the Balkan Peninsula. Phytol Balcan 15:175-179

Lenoir J, Hattab T, Pierre G (2017) Climatic microrefugia under anthropogenic climate change: implications for species redistribution. Ecography 40:253-266

Lindenmayer D, Thorn S, Banks S (2017) Please do not disturb ecosystems further. Nat Ecol Evol 1:0031

Maclean IMD, Suggitt AJ, Wilson RJ et al (2017) Fine-scale climate change: modelling spatial variation in biologically meaningful rates of warming. Glob Change Biol 23:256-268

Meineri E, Hylander K (2017) Fine-grain, large-domain climate models based on climate station and comprehensive topographic information improve microrefugia detection. Ecography 40:1003-1013

Mishra BP, Tripathi OP, Tripathi RS et al (2004) Effects of anthropogenic disturbance on plant diversity and community structure of a sacred grove in Meghalaya, northeast India. Biodivers Conserv 13:421-436

Morelli TL, Daly C, Dobrowski SZ et al (2016) Managing climate change refugia for climate adaptation. PLoS ONE 11:e0169725

Mucina L, Bültmann H, Dierßen K et al (2016) Vegetation of Europe: hierarchical floristic classification system of vascular plant, bryophyte, lichen, and algal communities. Appl Veg Sci 19:3-264 
O'Brien KR, Waycott M, Maxwell P et al (2018) Seagrass ecosystem trajectory depends on the relative timescales of resistance, recovery and disturbance. Mar Pollut Bull 134:166-176

Oksanen J, Blanchet FG, Kindt R et al (2018) Vegan: Community ecology. http://CRAN.R-project.org/ package= vegan

Özkan K, Gulsoy S, Mert A et al (2010) Plant distribution-altitude and landform relationships in karstic sinkholes of Mediterranean region of Turkey. J Environ Biol 31:51-60

Parise M, Pascali V (2003) Surface and subsurface environmental degradation in the karst of Apulia (southern Italy). Environ Geol 44:247-256

Pignatti S (2005) Valori di bioindicazione delle piante vascolari della flora d'Italia. Braun-Blanquetia 39:1-97

R Core Team (2018) R: a language and environment for statistical computing. Vienna, Austria: R Foundation for Statistical Computing. http://www.R-project.org/

Raschmanová N, Miklisová D, Kováč L' et al (2015) Community composition and cold tolerance of soil Collembola in a collapse karst doline with strong microclimate inversion. Biologia 70:802-811

Raschmanová N, Miklisová D, Kováč L' (2018) A unique small-scale microclimatic gradient in a temperate karst harbours exceptionally high diversity of soil Collembola. Int J Speleol 47:247-262

Růžička V, Mlejnek R, Juřičková L et al (2016) Invertebrates of the Macocha Abyss (Moravian Karst, Czech Republic). Acta Carsol 45:71-84

Saikh H, Varadachari C, Ghosh K (1998) Changes in carbon, nitrogen and phosphorus levels due to deforestation and cultivation: a case study in Simlipal National Park, India. Plant Soil 198:137-145

Serra-Diaz JM, Scheller RM, Syphard AD et al (2015) Disturbance and climate microrefugia mediate tree range shifts during climate change. Landsc Ecol 30:1039-1053

Somodi I, Virágh K, Podani J (2008) The effect of the expansion of the clonal grass Calamagrostis epigejos on the species turnover of a semiarid grassland. Appl Veg Sci 11:187-192

Soó R (1980) A magyar flóra és vegetáció rendszertani-növényföldrajzi kézikönyve VI. Akadémiai Kiadó, Budapest

Stančič L, Repe B (2018) Post-fire succession: selected examples from the Karst region, southwest Slovenia. Acta geogr Slov 58:27-38

Stylinski CD, Allen EB (1999) Lack of native species recovery following severe exotic disturbance in southern Californian shrublands. J Appl Ecol 36:544-554

Su Y, Tang Q, Mo F et al (2017) Karst tiankengs as refugia for indigenous tree flora amidst a degraded landscape in southwestern China. Sci Rep 7:4249

Suggitt AJ, Gillingham PK, Hill JK et al (2011) Habitat microclimates drive fine-scale variation in extreme temperatures. Oikos 120:1-8

Suggitt AJ, Wilson RJ, Isaac NJB et al (2018) Extinction risk from climate change is reduced by microclimatic buffering. Nat Clim Change 8:713-717

Sutton WRJ (1999) Does the world need planted forests? New Zeal J For 44:24-29

Syphard AD, Franklin J (2010) Species traits affect the performance of species distribution models for plants in southern California. J Veg Sci 21:177-189

Tan K, Perdetzoglou DK, Roussis V (1997) Biebersteinia orphanidis (Geraniaceae) from southern Greece. Ann Bot Fenn 34:41-45

Tichý L (2002) JUICE, software for vegetation classification. J Veg Sci 13:451-453

Tichý L, Chytrý M (2006) Statistical determination of diagnostic species for site groups of unequal size. J Veg Sci 17:809-818

Van Beynen P, Townsend K (2005) A disturbance index for karst environments. Environ Manag 36:101-116

van de Leemput IA, Dakos V, Scheffer M et al (2018) Slow recovery from local disturbances as an indicator for loss of ecosystem resilience. Ecosystems 21:141-152

Vojtkó A (2001) A Bükk hegység flórája, Sorbus 2001 Kiadó, Eger

Vojtkó A, Vojtkó E, Dulai S et al (2018) A fás vegetáció jellegzetességei az Alsó-hegy (Gömör-Tornaikarszt) karsztfennsíkján. Bot Közl 105:97-108

Walther GR, Post E, Convey P et al (2002) Ecological responses to recent climate change. Nature 416:389-395

Wezel A (2007) Changes between 1927 and 2004 and effect of rock climbing on occurrence of Saxifraga paniculata and Draba aizoides, two glacial relicts on limestone cliffs of the Swabian Jura, southern Germany. J Nat Conserv 15:84-93

Whiteman CD, Haiden T, Pospichal B et al (2004) Minimum temperatures, diurnal temperature ranges, and temperature inversion in limestone sinkholes of different sizes and shapes. J Appl Meteorol 43:1224-1236

Wraber T (1995) Cerastium dinaricum G. Beck \& Szysz.- - a new species in the flora of Slovenia. Hladnikia 4:11-18 
Yannitsaros AG, Constantinidis TA, Vassiliades DD (1996) The rediscovery of Biebersteinia orphanidis Boiss. (Geraniaceae) in Greece. Bot J Linn Soc 120:239-242

Zenner EK, Berger AL (2008) Influence of skidder traffic and canopy removal intensities on the ground flora in a clearcut-with-reserves northern hardwood stand in Minnesota, USA. Forest Ecol Manag 256:1785-1794

Zorn M, Kumer P, Ferk M (2015) Od gozda do gozda ali kje je goli, kamniti Kras? Kronika 63:561-574

Publisher's Note Springer Nature remains neutral with regard to jurisdictional claims in published maps and institutional affiliations.

\section{Affiliations}

\section{Zoltán Bátori $^{1}$ D $\cdot$ András Vojtkó ${ }^{2}$ Gunnar Keppel ${ }^{3,4} \cdot$ Csaba Tölgyesi $^{1}$.} Andraž Čarni ${ }^{5,6}$. Matija Zorn ${ }^{7}$ Tünde Farkas ${ }^{8}$. László Erdős ${ }^{9} \cdot$ Péter János Kiss ${ }^{1,10}$. Gábor Módra $^{1,10} \cdot$ Mateja Breg Valjavec ${ }^{7}$

1 Department of Ecology, University of Szeged, Közép fasor 52, 6726 Szeged, Hungary

2 Department of Botany, Eszterházy Károly University of Applied Sciences, Eszterházy tér 1, 3300 Eger, Hungary

3 Natural and Built Environments Research Centre, School of Natural and Built Environments, University of South Australia, Mawson Lakes Campus, GPO Box 2471, Adelaide, SA 5001, Australia

4 Future Industries Institute, University of South Australia, Mawson Lakes Campus, GPO Box 2471, Adelaide, SA 5001, Australia

5 Jovan Hadži Institute of Biology, Research Centre of the Slovenian Academy of Sciences and Arts, 1000 Ljubljana, Slovenia

6 School for Viticulture and Enology, University of Nova Gorica, Vipavska 13, 5000 Nova Gorica, Slovenia

7 Anton Melik Geographical Institute, Research Centre of the Slovenian Academy of Sciences and Arts, 1000 Ljubljana, Slovenia

8 Aggtelek National Park Directorate, Tengerszem oldal 1, 3758 Jósvafő, Hungary

9 MTA Centre for Ecological Research, Institute of Ecology and Botany, Alkotmány utca 2-4, 2163 Vácrátót, Hungary

10 Doctoral School of Environmental Sciences, University of Szeged, Rerrich Béla tér 1, 6720 Szeged, Hungary 